\title{
Thiazolidinediones Regulate the Level of $A B C$ Transporters Expression on Lung Cancer Cells
}

\author{
Thiazolidindiony ovlivňují úroveň exprese ABC transportérů \\ na buňkách karcinomu plic
}

\author{
Konieczna A. ${ }^{1,2}$, Novakova V. ${ }^{2}$, Medalova J. ${ }^{3}$, Erceg S. ${ }^{4}$, Klabusay M. ${ }^{4,5}$ \\ 'Department of Histology and Embryology, Faculty of Medicine and Dentistry, Palacky University, Olomouc, Czech Republic \\ 2 International Clinical Research Center, St. Anne's University Hospital, Brno, Czech Republic \\ ${ }^{3}$ Department of Animal Physiology and Immunology, Institute of Experimental Biology, Faculty of Science, Masaryk University, Brno, Czech Republic \\ ${ }^{4}$ Prince Felipe Research Center, Carrer d'Eduardo Primo Yúfera, Valencia, España \\ ${ }^{5}$ Department of Hematooncology and Department of Internal Medicine - Cardiology, Faculty of Medicine, Palacky University, Olomouc, Czech Republic \\ ${ }^{6}$ Department of Comprehensive Cancer Care, Masaryk Memorial Cancer Institute, Brno, Czech Republic
}

\begin{abstract}
Summary
ATP binding cassette $(A B C)$ transporters related to multidrug resistance (MDR) actively efflux various xenobiotics from the cells across the cell membrane and decrease a drug's efficiency. Lung cancer is the leading cause of death among all types of cancer in the Czech Republic, and its incidence is still rising. Ciglitazone, rosiglitazone and troglitazone belonging to PPAR- $\gamma$ agonist family (formerly used in diabetes mellitus treatment) were selected to investigate their capability to influence expression of $A B C$ transporters on lung cancer cells. Therefore, the effect of PPAR- $\gamma$ of agonists on transcription of following $A B C$ transporters was investigated: multidrug resistance protein 1 (MDR1), multidrug resistance-associated protein 1 (MRP1), and breast cancer resistance protein (BCRP). We have investigated if these PPAR- $\gamma$ agonists are substrates of ABC transporters using HL60 and HL60 derived cell lines (HL60-MDR1, HL60-MRP1, PLB-BCRP) by cytotoxicity test WST-1. We have mapped the changes in mRNA expression level of those transporters in A549 and HEK293 cells after PPAR- $\gamma$ agonists treatment using quantitative reverse transcription real-time PCR (qRT-PCR). All three PPAR- $\gamma$ agonists serve as substrates to at least one $A B C$ transporter under study. PPAR- $\gamma$ activation correlates with up-regulation of PTEN which may modulate the expression of $A B C$ transporters through PI3K/Akt signaling pathway. We have shown that rosiglitazone and troglitazone inhibit mRNA expression of MDR1 transporter in both cell lines whereas the expression of MRP1 in HEK293 cell was up-regulated after rosiglitazone treatment and the expression of MDR1 was upregulated after ciglitazone treatment.
\end{abstract}

\section{Key words}

multidrug resistance - ABC transporters - PI3K/Akt signaling pathway - PPAR- $\gamma$ agonists
This work was supported by European Regional Development Fund - Project FNUSAICRC (No. CZ.1.05/1.1.00/02.0123) and by the Internal Grant Agency of the Ministry of Health of the Czech Republic, Grant No. NS 9670-4.

Tato práce byla podpořena projektem European Regional Development Fund - Project (No. CZ.1.05/1.1.00/02.0123) a Interní grantovou agenturou MZ ČR, grantem č. NS 9670-4.

The authors declare they have no potential conflicts of interest concerning drugs, products, or services used in the study.

Autor̆i deklarují, že $v$ souvislosti s predmětem studie nemaji žádné komerční zájmy.

The Editorial Board declares that the manuscript met the ICMJE recommendation for biomedical papers.

Redakční rada potvrzuje, že rukopis práce splnil ICMJE kritéria pro publikace zasílané do biomedicínských časopisů.

$\varliminf^{\circ}$

Assoc. Prof. Martin Klabusay, PhD Department of Comprehensive Cancer Care

Masaryk Memorial Cancer Institute

Zluty kopec 7

65653 Brno

Czech Republic

e-mail: m.klabusay@sky.cz

Submitted/Obdrženo: 22. 5. 2015

Accepted/Prijato: 22. 6. 2015

http://dx.doi.org/10.14735/amko2015431 


\begin{abstract}
Souhrn
Východiska: $\mathrm{ABC}$ transportní proteiny odpovědné za MDR intenzivně pumpují různá xenobiotika z buňky a snižují tak účinek léků. Tyto proteiny přispívají ke vzniku rezistence také u karcinomu plic, který je vedoucí prí̌činou úmrtí mezi všemi typy nádorů v České republice a má rostoucí incidenci. Metody: Na buněčných liniích HL60 a také HL60-MDR1, HL60-MRP1 a PLB-BCRP bylo ověěeno pomocí cytotoxického testu WST-1, jestli ciglitazon, rosiglitazon a troglitazon (patřící do rodiny agonistů PPAR-y) jsou substráty následujících $A B C$ transportérů: multidrug resistance protein 1 (MDR1), multidrug resistance-associated protein 1 (MRP1) a breast cancer resistance protein (BCRP). Dále bylo testováno pomocí qRT-PCR, zda uvedené thiazolidindiony působí změnu exprese $A B C$ transportérů u buněčné linie nemalobuněčného adenokarcinomu plic ( $A 549$ ). Metodou Western blot bylo analyzováno, zda-li je tato exprese regulována signální dráhou PI3K/Akt. Výsledky: Bylo zjištěno, že všechny tři thiazolidindiony jsou substráty minimálně jednoho ze studovaných ABC transportérů. Aktivace receptoru PPAR- $\gamma$ koreluje s aktivací nádorového supresoru PTEN, který je zapojen do signální dráhy PI3K/Akt. Bylo prokázáno, že rosiglitazon a troglitazon výrazně inhibují expresi mRNA transportéru MDR1. Naproti tomu exprese transportérů MRP1 po ovlivnění rosiglitazonem a exprese transportérů MDR1 po ovlivnění ciglitazonem je aktivována. Závěr: Naše výsledky naznačují, že ze studovaných thiazolidindionů působí inhibičně pouze rosiglitazon a troglitazon, a to na expresi transportéru MDR1 na úrovni mRNA.
\end{abstract}

\title{
Klíčová slova
}

mnohočetná léková rezistence - ABC transportéry - signální dráha PI3K/Akt - agonisté PPAR- $\gamma$

\section{Introduction}

Multidrug resistance

Multidrug resistance (MDR) of cancer cells presents a serious problem in cytostatic drug therapy. Cancer cells become resistant to cytotoxic effect of chemotherapeutic drugs. High doses of chemotherapy may overcome this problem to some extent, but dose increase is often limited by side effects. MDR positive cancer cells are often selected by previous treatment and, as a result, cancer cells become resistant to treatment and drugs become ineffective for the patient [1].

Lung cancer is the leading cause of death among all types of cancer in the Czech Republic, and its incidence is still rising. It represents a serious problem in morbidity and mortality, especially among tobacco smokers. Moreover, although there are new drugs belonging to targeted cancer therapy available, none of these can cure advanced and inoperable lung cancer patients. Therefore, we chose lung cancer cell line as an important model for chemotherapy resistance investigation.

\section{ATP binding cassette transporters}

Numerous mechanisms contribute to MDR, but increased efflux of chemotherapeutic drugs because of overexpression of ATP binding cassette (ABC) transporters is the most common one [2]. $A B C$ transporters are transmembrane proteins that use ATP hydrolysis to transport various molecules across the cell membrane from the cytoplasm to the extracellular matrix [3]. In cancer cells, $A B C$ transporters function as pumps for eliminating chemotherapeutic drugs and thereby reducing the drugs cytostatic effect.

These pumps are present in a broad spectrum of human cancer cells including leukemia, lymphoma, multiple myeloma, and breast, prostate, ovarian, esophageal, kidney, liver and colon cancers [4-6]. Multidrug resistance phenotype in tumors is mostly associated with the overexpression of one or more of these $A B C$ transporters:

- ABCB1/PGP1/CD243/MDR1,

- ABCC1/GS-X/CD9/MRP1 and - ABCG2/MXR/CD338/BCRP [7].

\section{Substrate specificity}

Substrates of these three transporters are: vinca alkaloids, anthracyclines, antibiotics, anthraquinones, taxanes, epipodophyllotoxins, antimetabolites, antivirotics, camptothecins, antiandrogens, antihypertensive drugs, cardiac glycosides, corticosteroids, immunosuppressive drugs, opioid analgesics, toxins and other cytotoxic drugs [8].

\section{PI3K/Akt signaling pathway}

Overexpression of $A B C$ transporters is an unwanted finding in cancer cells, and it is one of the main factors characterizing MDR. MDR expression is regulated on a transcription level genetically and epigenetically and on post-transcriptional level, it is regulated by change in protein stability and by regulation of transport of $A B C$ transporters to a mem- brane [9]. Transcription of ABC transporters is regulated, among other ways, by signaling pathway of PI3K/Akt kinases. Receptors of PPARs are influenced by this pathway, as well.

Activation of PI3K/Akt kinase pathway is the triggering mechanism of resistance development in various types of cancers to cytostatic drugs. By inhibition of this pathway, enhancement of sensitivity of various cell lines to various chemotherapeutic drugs could be reached. Tumor suppressor PTEN inhibits physiologically PI3K/Akt kinase pathway through $\mathrm{PI} 3 \mathrm{P}$ dephosphorylation by PI3K (Fig. 1) [10].

\section{Peroxisome proliferator-activated receptor}

Peroxisome Proliferator-Activated Receptors (PPARs) are steroid nuclear receptors which act as transcription factors that regulate the expression of specific genes through peroxisome proliferator response elements (PPREs) [11,12]. They require heterodimerization with retinoid $X$ receptor (RXR) to start transcriptional activity [13]. Natural ligands of PPARs include fatty acids and eicosanoids. Synthetic ligands of PPARs include lipid lowering drugs (like fibrates) and insulin sensitizers (like thiazolidinediones), which are used in diabetes mellitus treatment. There is only one drug currently on the market now (pioglitazone), as the other ones demonstrated negative impact on heart failure in cardiac patients.

However, because of their action as PPAR- $\gamma$ agonists, we investigated the in- 


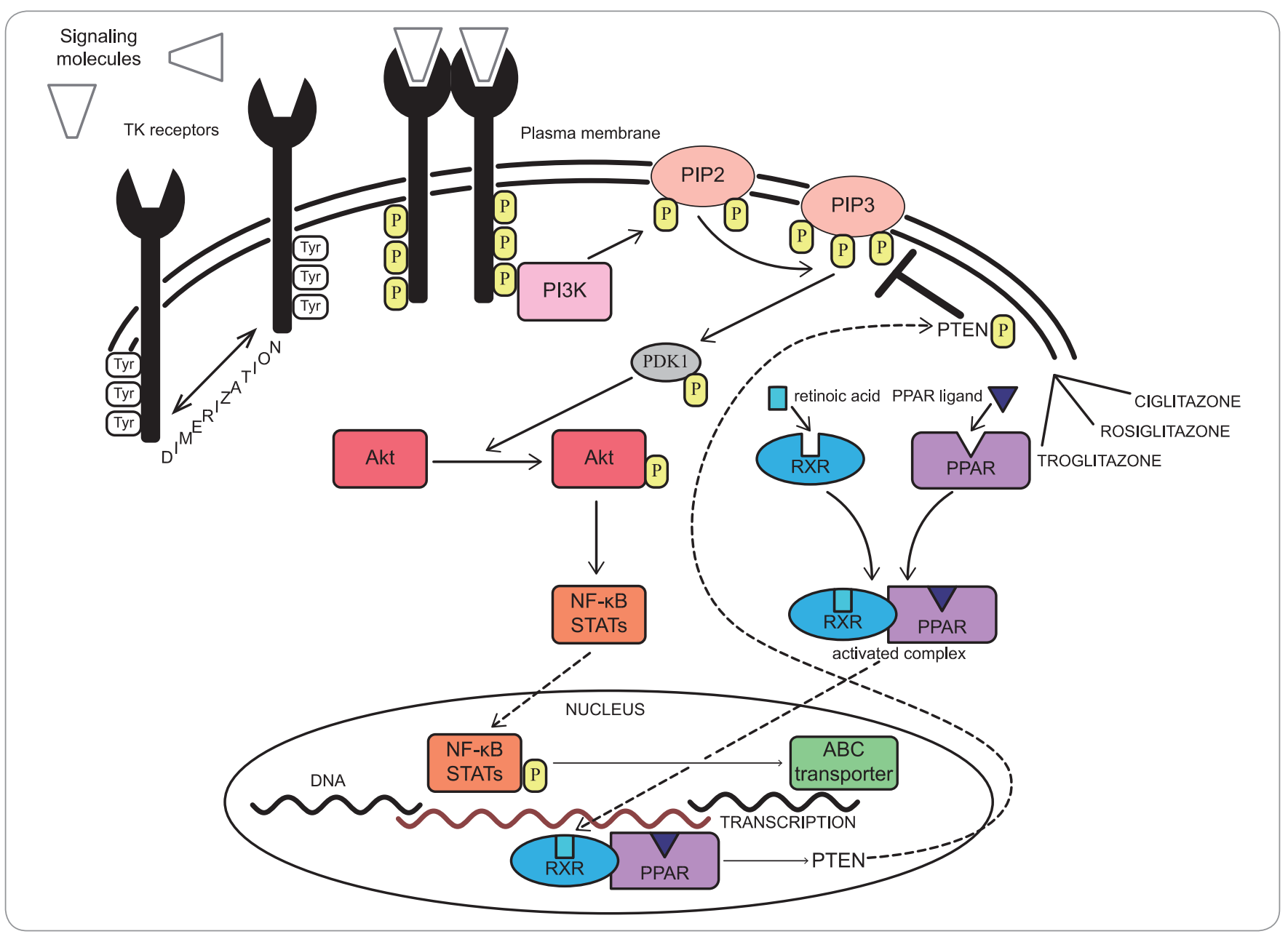

Fig. 1. Scheme of PI3K/Akt pathway regulating MDR-related $A B C$ transporters' expression.

fluence of three thiazolidinediones (ciglitazone, rosiglitazone and troglitazone) on the mRNA expression of these MDR-related $A B C$ transporters: multidrug resistance protein 1 - MDR1, multidrug resistance-associated protein 1 - MRP1, and breast cancer resistance protein BCRP in A549 and HEK293 cells using quantitative reverse transcription real-time PCR (qRT-PCR). We also studied the role of pPTEN on MDR-related transporters expression by western blotting and mapped the affinity of ciglitazone, rosiglitazone and troglitazone to MDR1, MRP1 and BCRP transporters in HL60 and HL60-MDR1, HL60-MRP1 and PLB-BCRP cell lines by cytotoxicity WST-1 test.

\section{Material and methods}

Human A549 (human non-small cell lung carcinoma cells) and HEK293 (human embryonic kidney 293 cells) were purchased from ATCC (CCL-185, CRL-1573),
HL60 (human promyelocytic leukemia cells) cells and cell lines overexpressing $A B C$ transporters related to MDR (HL60-MDR1, HL60-MRP1, and PLB-BCRP) were obtained from prof. Sarkadi (Hungarian Academy of Sciences, Budapest, Hungary). A549 cell line has features of cancer stem cells and expresses all three MDR-related ABC transporters. HEK293 cell line is a good model to study induction of $A B C$ transporters expression (due to its kidney origin, it contains genes for $A B C$ transporters). The cells were cultured in Dulbecco's modified Eagle's medium containing $10 \%(\mathrm{v} / \mathrm{v})$ fetal bovine serum, penicillin $(200 \mathrm{U} / \mathrm{mL})$, and streptomycin $(100 \mu \mathrm{g} / \mathrm{mL})$ at $37{ }^{\circ} \mathrm{C}$ in a humidified incubator with an atmosphere of $5 \% \mathrm{CO}_{2}$.

Cell viability/cytotoxicity assay WST-1 The assay is based on cleavage of the tetrazolium salt WST-1 to formazan by cellular mitochondrial dehydrogena- ses. Therefore, the amount of formazan dye formed directly correlates to the number of live cells in the culture.

The stock solution of the tested compounds was diluted in complete medium to give final concentration in the range of $1 \mu \mathrm{M}$ to $50 \mu \mathrm{M}$. The $\mathrm{HL}-60$ cell line and cell lines overexpressing $A B C$ transporters related to MDR (HL60-MDR1, HL60-MRP1, and PLB-BCRP) were seeded in triplicate in a 96-well culture plate at a density of 200,000 /well in total volume of $90 \mu \mathrm{l}$ and cultured for 24 hours. Cell viability was assessed after 48 hours incubation with tested compounds. WST-1 reagent (Roche) was added to the cells, and absorbance was determined at $420 \mathrm{~nm}$ using ELISA reader (Schoeller Instruments) after 1 hour incubation at $37^{\circ} \mathrm{C}$. Mean absorbance for each cell line was calculated from three measurements and normalized to the HL60 cell line. 
Tab. 1. Primers and probes used for specific amplification of $A B C$ transporters.

\begin{tabular}{|c|c|c|c|}
\hline Gene & $\begin{array}{l}\text { Forward primer - sequence } \\
\text { Reverse primer - sequence } \\
\text { Probes - sequence }\end{array}$ & GC (\%) & $\begin{array}{c}\text { Melting } \\
\text { temperature } \\
(\mathrm{Tm}) /{ }^{\circ} \mathrm{C}\end{array}$ \\
\hline \multirow{3}{*}{ MDR1 } & ACCCTAAAAACACCACTGGA & 45.00 & 57.02 \\
\hline & AATTACAGCAAGCCTGGAAC & 45.00 & 56.97 \\
\hline & CGCCAATGATGCTGCTCAAG & 55.00 & 55.00 \\
\hline \multirow{3}{*}{ MRP1 } & CTGTGGACTGCAAGTCTTTG & 50.00 & 57.01 \\
\hline & GGTAGACCCAGACAAGGATG & 55.00 & 57.00 \\
\hline & TGCTTCTGGCTCCCATCACC & 60.00 & 65.00 \\
\hline \multirow{3}{*}{$B C R P$} & GCATTCCACGATATGGATTT & 40.00 & 57.36 \\
\hline & AGGATTGTTTCCTGTTGCAT & 40.00 & 57.11 \\
\hline & TTGGGACAAAACTTCTGCCCA & 47.62 & 64.93 \\
\hline
\end{tabular}

Tab. 2. Affinity of $A B C$ transporters to tested drugs.

Tested drug

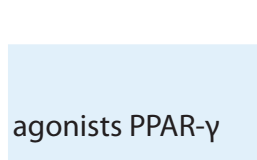

agonists PPAR- $\gamma$

\begin{tabular}{|l|c|c|c|}
\hline & MDR1 & MRP1 & BCRP \\
\hline ciglitazone & yes & - & - \\
\hline rosiglitazone & yes & yes & - \\
\hline troglitazone & yes & - & yes \\
\hline
\end{tabular}

\section{RNA isolation}

Cells were plated and grown to $90 \%$ confluence. After 24 hours, they were treated with IC50 quantities of ciglitazone, rosiglitazone and troglitazone and harvested after 1 hour, 6 hours, 1 day and 3 days. Total RNA was extracted from cells using the UltraClean Tissue \& Cells RNA Isolation Kit (MO BIO Laboratories). The concentration and purity of RNA were determined at 260 and 280 nm using NanoDrop 2000 (Thermo Scientific). Only those samples with ratios of A260 to A280 between 1.9 and 2.1 were considered further.

\section{Quantitative reverse transcription real-time PCR (qRT-PCR)}

The total amount of RNA was subjected to reverse transcription using RT kit plus (Elisabeth Pharmacon). Real-time PCR was performed using Master Mix (Generi Biotech) and dual-labeled Oligo:5'FAM-3' BHQ-1TaqMan probes (Generi Biotech) with the following amplification program: one cycle of $94{ }^{\circ} \mathrm{C}$ for $5 \mathrm{~min}$ and
45 cycles of $95^{\circ} \mathrm{C}$ for 10 seconds, $60^{\circ} \mathrm{C}$ for 10 seconds and $72{ }^{\circ} \mathrm{C}$ for 10 seconds. The primers and probes were designed using Primer3 (http://bioinfo.ut.ee/primer3/) and Beacon Designer (PREMIER Biosoft) software (Tab. 1). All experiments were performed with $\beta$-actin as internal control while using a real-time LightCycler 480 II (Roche). The fold-change of cDNA expression levels was determined from the obtained $\Delta \mathrm{Ct}$ values compared to $\Delta C t$ values of control samples.

\section{Western blot analysis}

A549 cells were plated and grown to $90 \%$ confluency. After 24 hours, they were treated with IC50 quantities of ciglitazone, rosiglitazone and troglitazone, rinsed with PBS and harvested after 1 day and 3 days in RIPA buffer containing $10 \mathrm{mM}$ TRIS- $\mathrm{Cl}$ ( $\mathrm{pH}$ 8.0), $1 \mathrm{mM}$ EDTA, 1\% SDS, $140 \mathrm{mM} \mathrm{NaCl}$, and protease and phosphatase inhibitor cocktail (PhosSTOP, Roche). Protein concentrations were measured by Bradford assay (Bio-Rad). Lysates were subjec- ted to SDS-PAGE and electrotransferred using Semi-Dry Electrophoretic Transfer Cell (Bio-Rad) to polyvinylidene difluoride membranes (Bio-Rad) for immunoblotting. Membranes were blocked for at least 1 hour in 5\% BSA/PBS/0.1\% tween 20 and probed with antibodies diluted in 5\% BSA/PBS (pPTEN Ser380/Thr382/Thr383 (sc-9549), $\beta$-actin (sc-4967), MCM7 (sc-4018), Cell Signaling Technology, PPARy (sc-81152), Santa Cruz Biotechnology). Primary antibody solution was incubated overnight at $4{ }^{\circ} \mathrm{C}$. Membranes were then washed three times with PBS and detected using HRP secondary antibodies (sc-7074, sc-7076, Santa Cruz Biotechnology), shown on film (CL-XPosure Film, Thermo Scientific) using an ECL Plus kit (GE Healthcare). Proteins were then re-probed using $\beta$-actin and GAPDH as loading controls.

\section{Statistical analysis}

Student t-test was used for statistical evaluation of qRT-PCR experiments (the values are given as the mean \pm SD of two independent experiments). In all tests, the value of $p \leq 0.05\left(^{*}\right)$ or the value of $p \leq 0.01\left(^{* *}\right)$ was considered as significant.

\section{Results}

Cell viability/cytotoxicity assay WST-1 Affinity of PPAR- $\gamma$ agonists towards MDR1, MRP1 and BCRP transporters was determined by WST-1 viability test. This experiment was performed on HL60 promyelocytic leukemia cell line with a very low level of $A B C$ transporters, and on transfected cell lines with overexpression of transporter of interest (HL60-MDR1, HL-60-MRP1, PLB-BCRP). It is assumed that influence of PPAR- $\gamma$ agonists will slow down cell proliferation [14]. Therefore, cells with high expression of particular transporter will grow faster than HL60 control cells.

As shown in Fig. 2, ciglitazone is a substrate of MDR1 transporter, rosiglitazone is a substrate of MDR1 and MRP1 transporter, and troglitazone is a substrate of MDR1 and BCRP transporter. The results are summarized in Tab. 2.

Expression of MDR1, MRP1 and BCRP transporters after use of agonists PPAR- $\gamma$ 


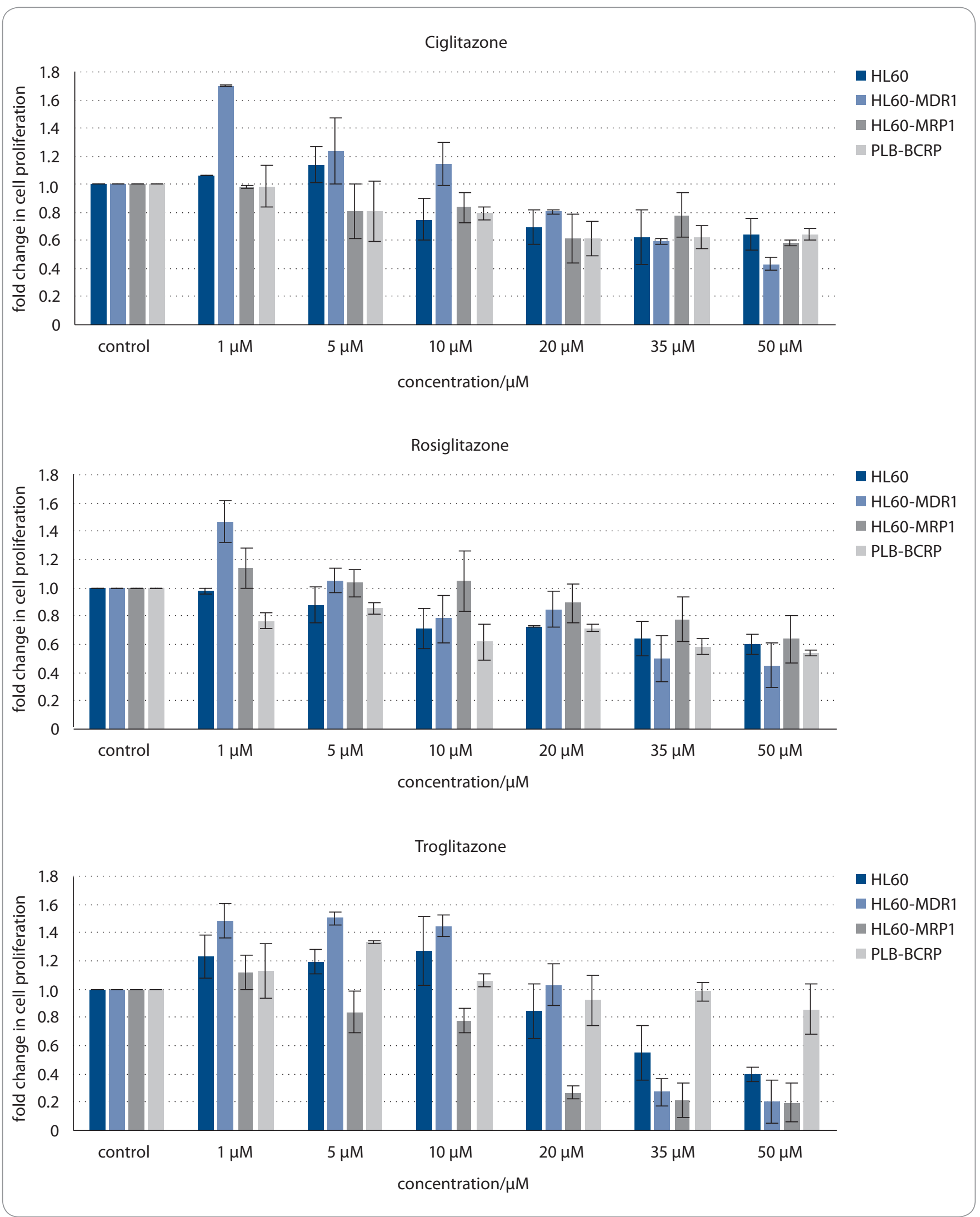

Fig. 2. Differential proliferation of HL60, HL60-MDR1, HL60-MRP1, and PLB-BCRP cell lines in the presence of 1-50 $\mu$ M ciglitazone (A), 1-50 $\mu \mathrm{M}$ rosiglitazone (B), and 1-50 $\mu \mathrm{M}$ troglitazone (C) as established by WST-1 cell viability/cytotoxicity assay.

Data were normalized to the HL60 cell line. The mean \pm SD indicate standard deviation from the mean for three independent experiments. 


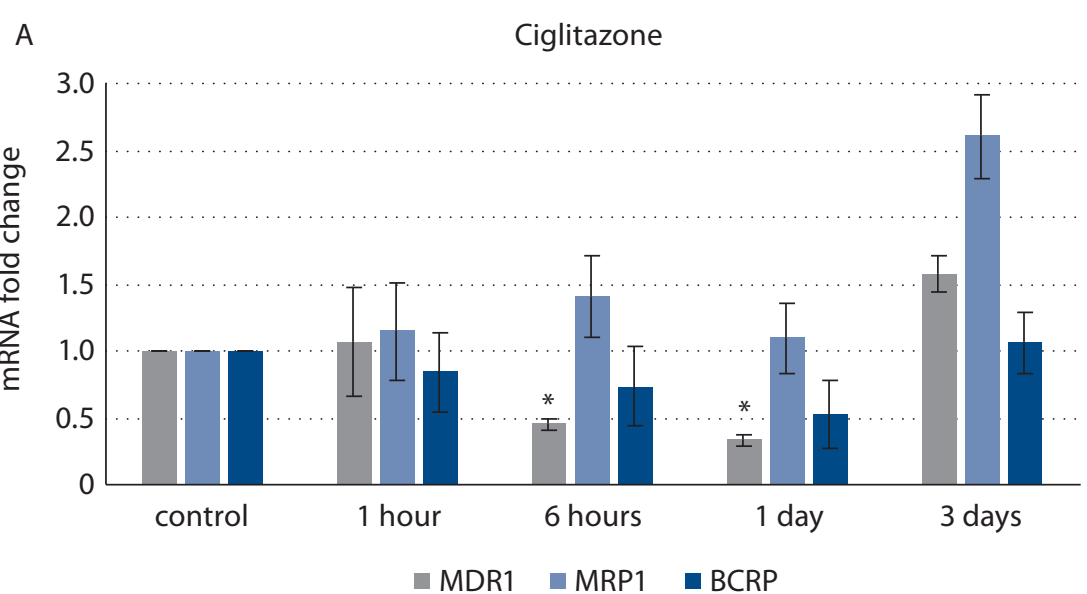

B

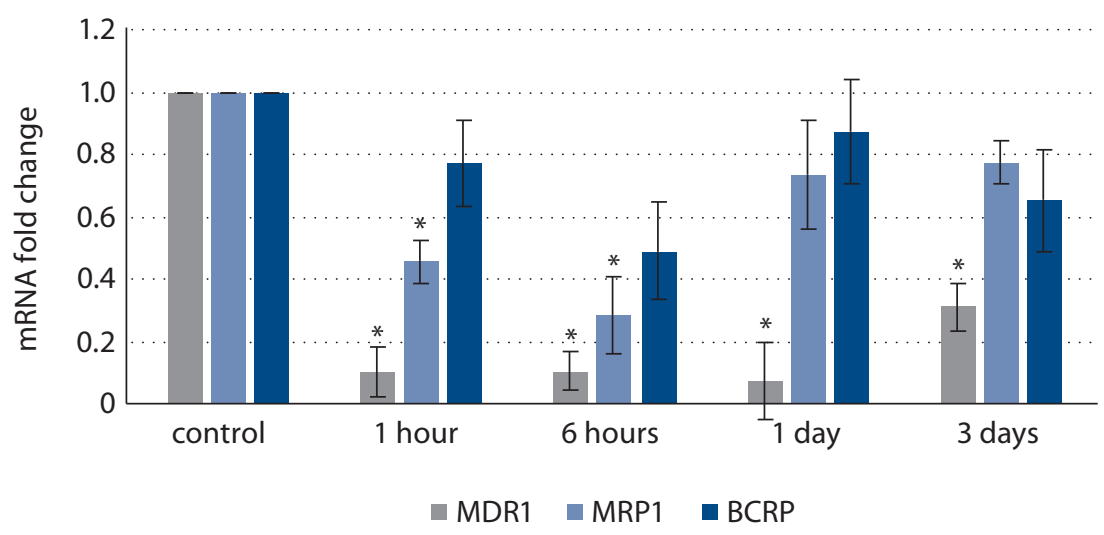

C

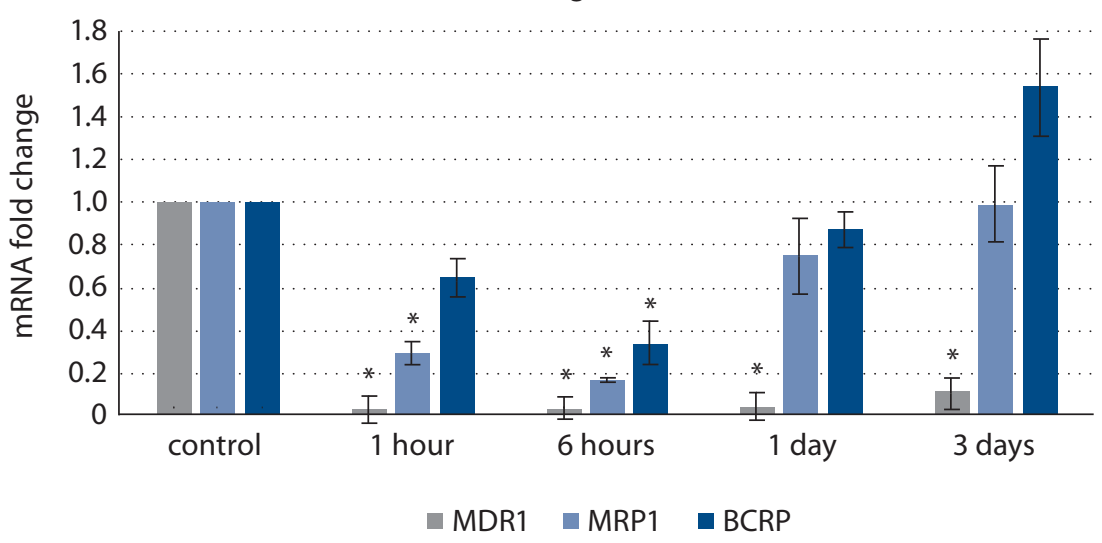

Fig. 3. Expression of MDR1, MRP1 and BCRP mRNA as measured by qRT-PCR in A549 cell line after IC50 ciglitazone treatment (A), after IC50 rosiglitazone treatment (B), after IC50 troglitazone treatment (C), in HEK293 cell line after IC50 ciglitazone treatment (D), after IC50 rosiglitazone treatment (E), after IC50 troglitazone treatment (F).

Data were normalized to control (untreated) cells. The mean \pm SD indicate standard deviation from the mean for two independent experiments, a value of $p \leq 0.05\left(^{*}\right)$ or a value of $p \leq 0.01\left(^{* *}\right)$ was considered as significant. in cell lines A549 and HEK293 (see Fig. 3) were determined by qRT-PCR. Endogenous expression of all three $A B C$ transporters is very low in HEK293 cells. Thus, these cells are useful for studying such processes which do not happen spontaneously. On the other hand, expression of all three transporters is high in A549 cells. Thus, these cells are an excellent model for established drug resistance.

PPAR- $\gamma$ agonists inhibit effectively mRNA expression only for MDR1 transporter. Ciglitazone is the only drug which activates expression of this transporter (31 times) in HEK293 cells after day 3 . In these cells, rosiglitazone activates expression of MRP1 transporter (58 times), and also BCRP transporters (16 times).

For understanding the role of PPAR- $\gamma /$ /PTEN proteins in the process of $A B C$ transporters regulation, expression of proteins PPAR $-\gamma$ and phosphorylated PTEN (on Ser380/Thr382/Thr383 amino acids) after exposure to PPAR- $\gamma$ agonists was detected by western blot. At day 3 after PPAR- $\gamma$ agonists exposure, increased inexpression of PPAR- $\gamma$ and phosphorylated form of pPTEN was observed. It was shown that PPAR- $\gamma /$ PTEN are negative regulators of expression of $A B C$ transporters responsible for MDR see Fig. 4.

\section{Discussion}

With the use of quantitative PCR with reverse transcription ( $q R T-P C R$ ), influence of PPAR- $\gamma$ agonists on transcription of MDR1, MRP1 and BCRP was studied. Rosiglitazone and troglitazone inhibited effectively expression of mRNA of transporter MDR1 in both cell lines. In concordance, Davies et al. reported lowering of expression of MDR1 transporter and sensitivity re-establishment in these cell lines to doxorubicin [15] (in MCF-7 breast cancer cell lined and in leukemic cell line K562) because of the effect of troglitazone.

Szatmari et al. demonstrated that PPAR- $\gamma$ directly induces expression of transporter BCRP by transcription in human monocyte-derived human dendritic cells and in myeloid leukemia cell line MM6. They identified and characterized conservative chain, length 


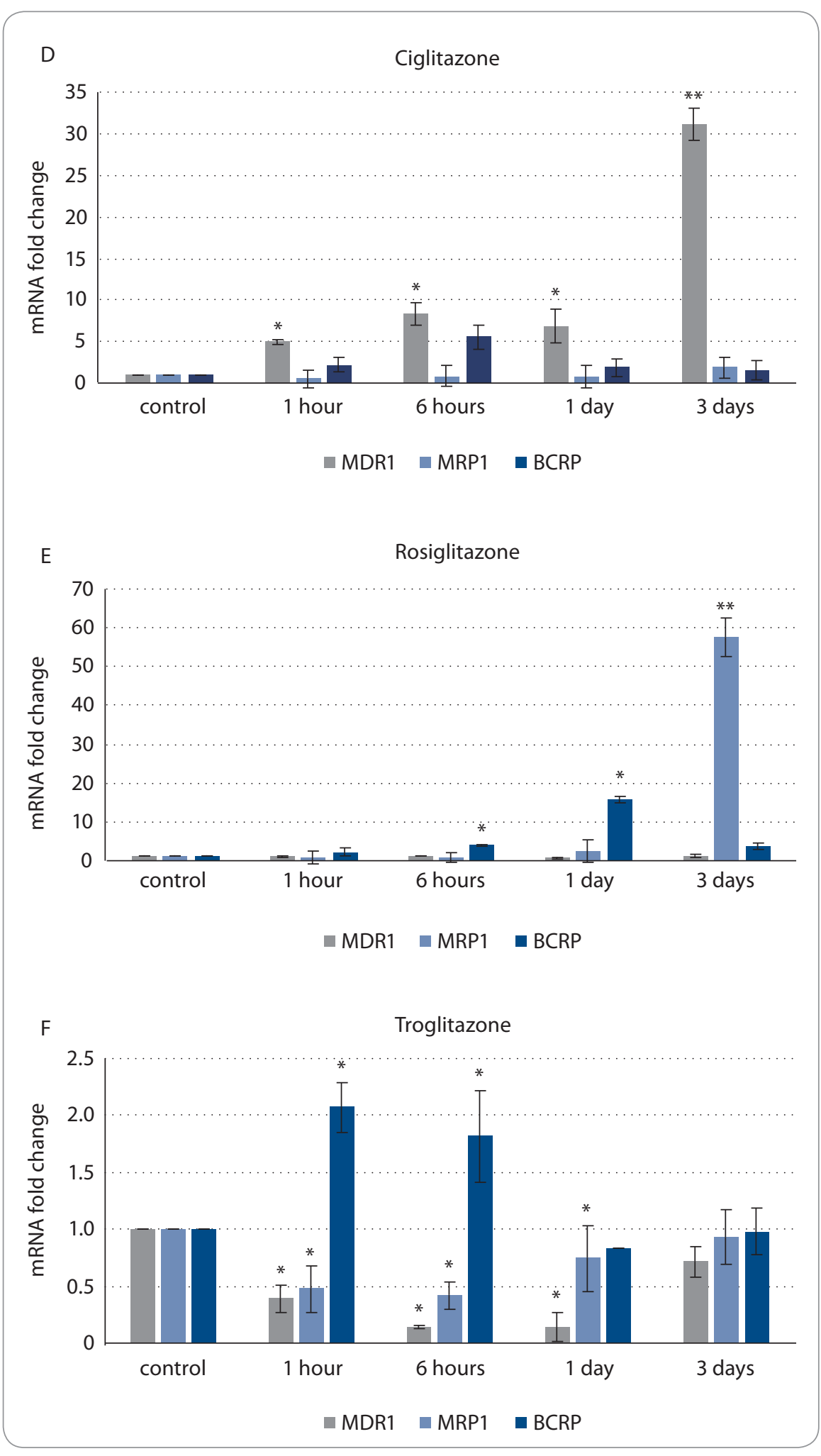

Fig. 3 - continuation. Expression of MDR1, MRP1 and BCRP mRNA as measured by qRT-PCR in A549 cell line after IC50 ciglitazone treatment (A), after IC50 rosiglitazone treatment (B), after IC50 troglitazone treatment (C), in HEK293 cell line after IC50 ciglitazone treatment (D), after IC50 rosiglitazone treatment (E), after IC50 troglitazone treatment (F).

Data were normalized to control (untreated) cells. The mean \pm SD indicate standard deviation, a value of $p \leq 0.05\left(^{*}\right)$ or a value of $p \leq 0.01\left(^{* *}\right)$ was considered as significant.

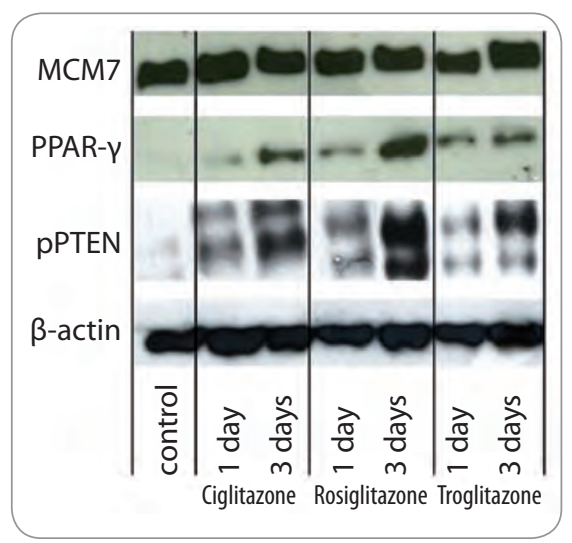

Fig. 4. PPAR- $\gamma$ agonists-modulated expression of pPTEN in A549 cell line.

of $150-\mathrm{pb}$, containing three functional sequences PPRE „up-stream" from human gene BCRP. All three contain direct repetitions DR- 1 which are capable of binding PPAR- $\gamma /$ RXR heterodimers [15]. In MDR1 and MRP1 transporters, no PPRE region was found to date; however, the presence of RXR binding site at MDR1 was found [17].

Davies et al. noticed decrease of expression of BCRP transporters. Therefore, it seems likely that PPAR- $\gamma$ agonists can influence BCRP transporter expression not only by direct binding of activated receptor to PPRE transporter (induction of expression), but also indirectly - mainly through signaling pathway PI3K/Akt (inhibition of transcription) - by activation of transcription of tumor suppressor PTEN $[18,19]$.

Weiss et al. found that function of transporter BCRP is inhibited by troglitazone and rosiglitazone (although mRNA expression of this transporter was induced). On the other hand, transporter MDR1 is inhibited in function, as well as in decreased mRNA expression [20].

Inhibition of transporter MDR1 transcription by troglitazone was proven in gastric cancer cell line SGC7901 resistant to vincristine [21]. In human osteosarcoma cell line 143B resistant to doxorubicin, elevated expression of transporter MDR1 and Kruppel-like factor 2 (i.e. specific PPAR- $\gamma$ suppressor [22]) was proven [23]. Ehrhard et al. inhibited transcription of MDR1 transporter by phenolfibrate in cell line LLC-PK1 (from pig kidney epithelial cells) and in cell line L-MDR1 (derived from 
previous one, but transfected with gene coding MDR1) [24]. These studies confirm negative regulation of MDR1 by PPAR- $\gamma$.

Activation of tumor suppressor PTEN was confirmed by western blotting. PTEN inhibits physiologically signaling pathway $\mathrm{PI} 3 \mathrm{~K} / \mathrm{Akt}$ by dephosphorylating phosphatidylinositol (3,4,5)-trisphosphate (phosphorylated by PI3K [10]). It was proven that specific PI3K inhibitor, LY294002, inhibited resistance to vincristine, which was transported by MDR1 pump in L1210/VCR cells [25]. In our experiments, we noticed elevated expression of phosphorylated PTEN at day 3 after treatment with PPAR- $\gamma$ agonist. This finding is verified by the fact that PPAR- $\gamma$ agonists inhibit signaling pathway PI3K/Akt because of PTEN activation.

\section{Conclusions}

Ciglitazone, rosiglitazone and troglitazone are substrates of MDR1 transporter, rosiglitazone is moreover a substrate of MRP1 transporter, troglitazone is a substrate of BCRP transporter. Rosiglitazone and troglitazone inhibit the expression of MDR1 transporter on mRNA level. PPAR- $\gamma$ agonists activate tumor suppressor PTEN which inhibits PI3K/Akt signaling pathway (playing a crucial role in the regulation of $A B C$ transporters related to MDR expression).

\section{References}

1. Ozben T. Mechanisms and strategies to overcome multiple drug resistance in cancer. FEBS Lett 2006; 580(12): 2903-2909

2. Gottesman MM. Mechanisms of cancer drug resistence Annu Rev Med 2002; 53: 615-627.

3. Hyde SC, Emsley P, Hartshorn MJ et al. Structural mode of ATP-binding proteins associated with cystic fibrosis, multidrug resistance and bacterial transport. Nature 1990; 346(6282): 362-365.

4. Goldstein L, Galski H, Fojo A et al. Expression of a multidrug resistance gene in human cancers. JNCl Cance Spectrum 1989; 81(2): 116-124.

5. Nooter K, Westerman AM, Flens MJ et al. Expression of the multidrug resistance-associated protein (MRP) gene in human cancers. Clin Cancer Res 1995; 1 (11): 1301-1310. 6. Robey RW, Polgar O, Deeken J et al. ABCG2: determining its relevance in clinical drug resistance. Cancer Metastasis Rev 2007: 26(1): 39-57.

7. Dean M. The human ATP-binding cassette (ABC) transporter superfamily. J Lipid Res 2001; 42(7): 1007-1017.

8. Avedano C, Mendez JC. Inhibitors of multidrug resistance to antitumor agents (MDR). Curr Med Chem 2002; 9(2): 159-193.

9. Scotto KW. Transcriptional regulation of $A B C$ drug transporters. Oncogene 2003; 22(47): 7496-7511.

10. Tamura M, Gu J, Danen EH et al. PTEN interactions with focal adhesion kinase and suppression of the extracellular matrix-dependent phosphatidylinositol 3-kinase/Akt cell survival pathway. J Biol Chem 1999; 274(29): 20693-20703.

11. Robyr D, Wolffe AP, Wahli W. Nuclear hormone receptor coregulators in action: diversity for shared tasks. Mo Endocrinol 200; 14(3): 329-347.

12. Isseman I, Green S. Activation of a member of the steroid hormone receptor superfamily by peroxisome proliferators. Nature 1990; 347(6294): 645-650.

13. Kliewer SA, Umesono K, Noonan DJ et al. Convergence of 9-cis retinoic acid and peroxisome proliferator signalling pathwas through heterodimer formation of their receptors. Nature 1992; 358(6389): 771-774.

14. Placha W, Gil D, Dembińska-Kieć A et al. The effect of PPARgamma ligands on the proliferation and apoptosis of human melanoma cells. Melanoma Res 2003; 13(5): 447-456
15. Davies GD, Juurlink BH, Harkness TA. Troglitazone reverses the multiple drug resistance phenotype in cancer cells. Drug Des Devel Ther 2009; 3: 79-88.

16. Szatmari I, Vamosi G, Brazda P et al. Peroxisome proliferator-activated receptor gamma-regulated ABCG2 expression confers cytoprotection to human dendritic cells. J Biol Chem 2006; 281(33): 23812-23823.

17. Kurose K, Saeki M, Tohkin M. Thyroid hormone receptor mediates human MDR1 gene expressionidentification of the response region essential for gene expression. Arch Biochem Biophys 2008; 474(1): 82-90. doi: 10.1016/j.abb.2008.03.020

18. Yang ZC, Tsao YP, Ho TC et al. Peroxisome proliferator-activated receptor-gamma agonists cause growth arrest and apoptosis in human ovarian carcinoma cell lines. Int J Gynecol Cancer 2007; 17(2): 418-425.

19. Cao LQ, Chen XL, Wang Q et al. Upregulation of PTEN involved in rosiglitazone-induced apoptosis in human hepatocellular carcinoma cells. Acta Phamacol Sin 2007; 28(6): 879-887

20. Weiss J, Sauer A, Herzog M et al. Interaction of thiazolidinediones (glitazones) with the ATP-binding cassette transporters P-glycoprotein and breast cancer resistance protein. Pharmacology 2009; 84(5): 264-270. doi: 10.1159/000241 734.

21. Rajkumar T, Yamuna M. Multiple pathways are involved in drug resistance to doxorubicin in an osteosarcoma cell line. Anticancer Drugs 2008; 19(3): 257-265.

22. Chen Q, Zhou J, Jiang C et al. Reversal of P-glycoprotein-mediated multidrug resistance in SGC7901/VCR cells by PPARY activation by troglitazone. J Huazhong Univ Sci Technolog Med Sci 2010; 30(3): 326-331. doi: 10.1007/s11596-010-0351-6.

23. Schober SL, Chay K, Schluns KS et al. Expression of the transcription factor lung Krüppel-like factor is regulated by cytokines and correlates with survival memory T cells in vitro and in vivo. J Immunol 1999; 163(7): 3662-3667.

24. Ehrhard M, Lindenmaier H, Burhenne J et al. Influence of lipid lowering fibrates on P-glycoprotein activity in vitro. Biochem Pharmacol 2004; 67(2): 285-292.

25. Barancík M, Bohácová V, Sedlák J et al. LY294,002, a specific inhibitor of PI3K/Akt kinase pathway, antagonizes P-glycoprotein-mediated multidrug resistance. Eur J Pharm Sci 2006; 29(5): 426-434. 